\title{
Effect Of Multimedia-Based Gymnastics Method And Obesity Of Fat Reduction At The Waist
}

\author{
Eva Faridah, Soegiyanto KS, Nasuka, Sulaiman
}

\begin{abstract}
Gymnastics is a gesture carried out in a certain way at a certain speed to train members of the entire body. Multimedia learning is presented visually in the form of moving images that can display gymnastics in order to decrease fat at the waist. The purpose of this study is to compare and evaluate between Pilates gymnastic methods and hula hoop gymnastic methods and obesity levels to reduce fat at the waist. The research method used was Pilates gymnastics method and hula gymnastic method that uses multimedia. This study is expected to produce the availability of guidance in the form of text, audio, visual and video for someone who will carry out gymnastics. So that it can be concluded that gymnastics using multimedia as an additional device can more quickly achieve the desired results.
\end{abstract}

Keywords: Gymnastics, Multimedia, Pilates Gymnastics, Hula Hoop Gymnastics.

\section{INTRODUCTION}

Sport has become a social phenomenon spread throughout the world. Sports can be used and directed for various purposes (1). However, every country in the world including Indonesia faces the challenge of increasing and maintaining the physical fitness of its citizens (2). Excessive weight due to fat makes it slow movements to the extent that obese people are usually lazy to move their weight. It turns out that excessive fat, from the results of the study,(3) is not the result of just overeating but rather a fairly complex fabric, including genetic factors, excessive exercise habits, daily eating habits,(4) hormones, and gender. In the era of globalization, technological development has developed rapidly both (5) in the fields of agriculture, industry or in the health sector. The development of this technology makes the work (6) that was initially felt heavy requires a lot of energy to be light and it is easy to do because of the energy savings. Excess energy is stored under the skin so called fat when it accumulates high, then humans will become fat, and if the total amount of fat in the body is enlarged then humans will be overweight If the fat in the body exceeds that of normal conditions will be a big problem. Besides, the body looks less attractive a number of diseases will come to approach

Revised Manuscript Received on April 19, 2019.

Eva Faridah, S.Pd., M.Or., Physical education Pascasarjana Universitas Negeri Semarang, Indonesia

Faculty of Sport Sciences, Universitas Negeri Medan, Indonesia

Prof. Dr. Soegiyanto KS, MS, Physical education Pascasarjana Universitas Negeri Semarang, Indonesia

Dr. Nasuka, M.Kes, Physical education Pascasarjana Universitas Negeri Semarang, Indonesia

Dr. Sulaiman, M.Pd, Physical education Pascasarjana Universitas Negeri Semarang, Indonesia such as diabetes mellitus, heart disease, hypertension, and for women (7) it can cause menstrual disorders and reduce self-confidence because the body shape is not ideal. This happens because of excess food intake for a long time without being balanced with sufficient activity to burn energy or called an imbalance between energy intake that exceeds the energy used (energy expenditure). So that gradually the excess energy will be converted into fat and deposited in the fat cells under the skin, and consequently the person becomes fat. Overweight or obesity occurs due to the absence of a balance (8) between incoming energy or intake with the energy that comes out that is used for activities or for daily activities. These problems make especially productive mothers aged between 30-50 years (9) think about how to overcome the problem so that obesity does not occur and accumulate fat on the body, especially in the fat around the waist. (10) Fat is divided into two groups, namely saturated fat and unsaturated fat (11). One type of aerobic exercise is gymnastics and dance. In this study, the difference in the influence of body language gymnastics and rhythmic exercise using hula-hoop to decrease waist fat levels in productive age mothers between $30-50$ years.

\section{LITERATURE REVIEW}

Fat is a group of organic bonds consisting of elements of Carbon $(12)(\mathrm{C})$, Hydrogen $(\mathrm{H})$ and Oxygen $(\mathrm{O} 2)$, Fats in the body function to reserve energy to defend the body from external disturbances such as blows or harmful substances such as chemicals which can damage muscle (13) tissue and give lines of good body shape Fat tissue which is mainly under the skin and covers organs in the abdominal cavity. Fat in our body consists of triglycerides, fatty acids (14) (fatty acids) and cholesterol. Factors that affect fat at the waist are: Genetic. The possibility of BBL (over weight) (15) (16) is greater if one or both obese parents. Being old makes people tend to be less active. (17) Besides, there is also a decrease in the amount of muscle that lowers metabolism. All of this reduces calorie requirements. Diet refers to consumption of high calorie foods such as fast food on a regular basis coupled with soft drinks, candy and desserts contribute to an increase in BB (Weight).(18) Physical inactivity,(19) in which sedentary lifestyle does not burn calories. Fat accumulation in the waist of woman 
excess fat is in the middle part of the body, namely the waist. The problem that occurs with body weight in a person is if someone overweight Sunita Almatsier.

\section{METHODOLOGY/MATERIALS}

The research method used is the study was experimental method. The design used in this study was $2 \times 2$ factorial design.

Table 1. Factorial $2 \times 2$ design

Information :

a1b1: Groups of Mothers who participate in Body language Gymnastics in the category of High Flexibility

a1b2: Groups of Mothers who participate in Body Language Gymnastics with a low flexibility category

a2b1: Groups of Mothers who take part in Rhythmic Exercise use Hula-hoop in the category of High Flexibility

a2b2: Groups of Mothers who participate in Rhythm Exercise Using Hula-hoop in the category of Low Flexibility

In this study involved three variables, namely independent variables, attributive variables and dependent variables. The details are as follows:

1. The independent variable (independent) is a variable that affects other variables. The independent variable in this study are:

a. Manipulative variables, which consist of Gym Language Body and Rhythmic Gymnastics Using Hulahoop

b. Attributive variable, is a variable that is attached to the sample and becomes the nature of the sample. The attributive variables in this study consist of: (1) High Flexibility and (2) Low Flexibility.

2. Dependent variables are variables that are influenced by other variables. The dependent variable in this study is a decrease in fat levels at the waist.

In gymnastics studios, there are also exercises that help to reduce fat, one of which is hula-hoop made of rattan with a circular shape. Gymnastic body language and rhythmic exercise using hula-hoop and body flexibility are the inspiration for researchers to implement the gymnastics training program in an effort to reduce fat levels in the waist for productive age mothers of 30-50 years. Knowing the fat deposits in the abdominal cavity can be seen through a

\begin{tabular}{|c|c|c|}
\hline $\begin{array}{l}\text { Atributive } \\
\text { Variables } \\
\text { Manipulative } \\
\text { Variable }\end{array}$ & $\begin{array}{c}\text { High } \\
\text { Flexibility } \\
\left(b_{1}\right)\end{array}$ & $\begin{array}{l}\text { Low Flexibility } \\
\qquad\left(\mathbf{b}_{2}\right)\end{array}$ \\
\hline $\begin{array}{l}\text { body } \\
\text { language } \\
\text { gymnastic } \\
\left(\mathrm{a}_{1}\right) \\
\end{array}$ & $\mathbf{a}_{1} \mathbf{b}_{1}$ & $\mathbf{a}_{1} \mathbf{b}_{2}$ \\
\hline $\begin{array}{l}\text { rhythmic } \\
\text { gymnastics } \\
\text { using hula } \\
\text { hoop }\left(a_{2}\right)\end{array}$ & $\mathbf{a}_{2} \mathbf{b}_{1}$ & $\mathbf{a}_{2} \mathbf{b}_{2}$ \\
\hline
\end{tabular}

comparison between waist circumference size and hip circumference or better known as the waist and hip ratio (waist to hip ratio). The method can be measured based on the distribution of fat in the body, waist circumference is measured just above the navel, while the hip circumference is measured right in the middle of the buttocks. To get a BBR value (Relative Weight), simply divide the weight (in kilograms / kg) with height (in centimeters / cm) after minus 100 , the result is multiplied by $100 \%$. Mathematically is $\mathrm{x}$ $100 \%$. The result if the BBR value is greater than 120 means we are overweight,

To reduce fat in the body, we really need to pay attention to the menu of food we consume, among others, reduce the following types of food: Fried foods, Creams containing fat, Butter and animal fat, Milk and mayonnaise (use non-fat milk and mild mayonnaise), fatty meat (removing fat before cooking) and cakes and biscuits. And to eliminate body fat: Don't eat food left by others, chew food thoroughly, avoid consumption of fast food, practice gymnastics regularly and regularly, consume foods that are low in fat, drink plenty of water, consume complex carbohydrates and not simple sugars (simple sugar), consume protein in sufficient quantities unless it is recommended to increase protein intake by doctors (some people need more protein than others).

\section{RESULTS AND FINDINGS}

To get maximum results, there are several factors that need to be considered, namely: 1. Exercise intensity (Intensity of training), Exercise intensity is one of the important factors in training for the results of the formation of waist circumference, 2. Duration of Training, The length of this exercise is based on the Lynee Brick table (2002: 5859) about the length of training for low impact aerobic training programs, 3. Frequency of Training, frequency of training in this study based on table Lynee Brick (2002: 5859) about the frequency of training for aerobic exercise programs, 4. "Repeat core training continuously until the target reaches 60 minutes per training session, and rest for each change of gymnastics session for a maximum of 1-3 minutes" Number of Repetitions, 5. Overload (Overload), the more often we do the exercises, will increase the burning of fat in the body of the waist. So far to measure body fat as a mirror of obesity is often used the method of body mass index (BMI), by dividing the value of body weight $(\mathrm{kg})$ with height (in meters squared). If the result is $>25$, the body is overweight or obese. To start reducing excess fat in the middle part of the body, namely the waist, we need to increase metabolism and become more active. Strong, fast and rhythmic movements that use large muscles in the body, including the waist muscles, are needed to make the heart and lungs work harder to absorb more oxygen needed in the process of fat metabolism. One way to overcome obesity requires an activity that is able to burn fat. One of them is gymnastics that uses music that makes the activity of doing gymnastics become more energetic so that the feelings of the heart are also happy and happy. Gymnastics, especially 
body language (BL) and rhythmic exercises. The creator of the Body Language (BL) gymnastic movement is Roy Tobing who has a choreographer background. If this exercise is done correctly and correctly, it can produce a beautiful body shape with good flexibility, in addition to maintaining stamina. The body language teaches also how to breathe well, namely combining gymnastic movements with the correct breathing method. As a result, stamina and good body health. The benefits of the Body language will be very visible if done correctly and regularly. The body language prioritizes useful movements, directly affecting the body muscles, so that muscle formation and flexibility will occur according to the function of the movement itself. Because it is done with the right technique and power, it will burn calories. The results of body language gymnastics will provide benefits or benefits Body language (BL) exercises for women are: Growing self-confidence, having an ideal / proportional body shape (chest, waist, hips and thighs), the body becomes healthy, fit and youthful, and add harmony to the household, facilitate breathing. However, it should also be noted that the weaknesses or disadvantages of doing Body Language (BL) exercises for women are; Gymnastics body language including gymnastics in the category of slow or low impact because of the concentration of movement on breathing and swaying for the movement of the whole body. Gymnastic body language is less energetic or less agile because the main concentration is exercise gymnastics.

Table 2. Description of Data on Levels of Fat at Waist Tests for Each Group Based on Use of Gymnastic Exercises and Flexibility

\begin{tabular}{|c|c|c|c|c|c|}
\hline Treatment & Flexibility & Statistics & $\begin{array}{l}\text { Pre-test } \\
\text { result }\end{array}$ & $\begin{array}{c}\text { Pest-test } \\
\text { result }\end{array}$ & $\begin{array}{c}\text { Decreasing } \\
\text { Fat Levels } \\
\text { at the } \\
\text { Waist }\end{array}$ \\
\hline \multirow{6}{*}{$\begin{array}{l}\text { Gymnastic with } \\
\text { Body language }\end{array}$} & \multirow{3}{*}{ High } & Total & 76400 & 726.00 & 38.00 \\
\hline & & Average & 76.400 & 72600 & 3.800 \\
\hline & & SD & 7336 & 7121 & 1.619 \\
\hline & \multirow{3}{*}{ Low } & Total & 803.00 & 73600 & 67,00 \\
\hline & & Average & 80.300 & 73.600 & 6.700 \\
\hline & & SD & 8.693 & 8893 & 1889 \\
\hline \multirow{6}{*}{$\begin{array}{l}\text { Rhythmic Exercise } \\
\text { using bolahop }\end{array}$} & \multirow{3}{*}{ High } & Total & 783.00 & 714.00 & 69.00 \\
\hline & & Average & 78.300 & 71.400 & 6.900 \\
\hline & & SD & 9.753 & 8.462 & 2234 \\
\hline & \multirow{3}{*}{ Low } & Total & 758.00 & 693.00 & 65.00 \\
\hline & & Average & 75.800 & 69300 & 6500 \\
\hline & & SD & 9.426 & 10.067 & 1581 \\
\hline
\end{tabular}

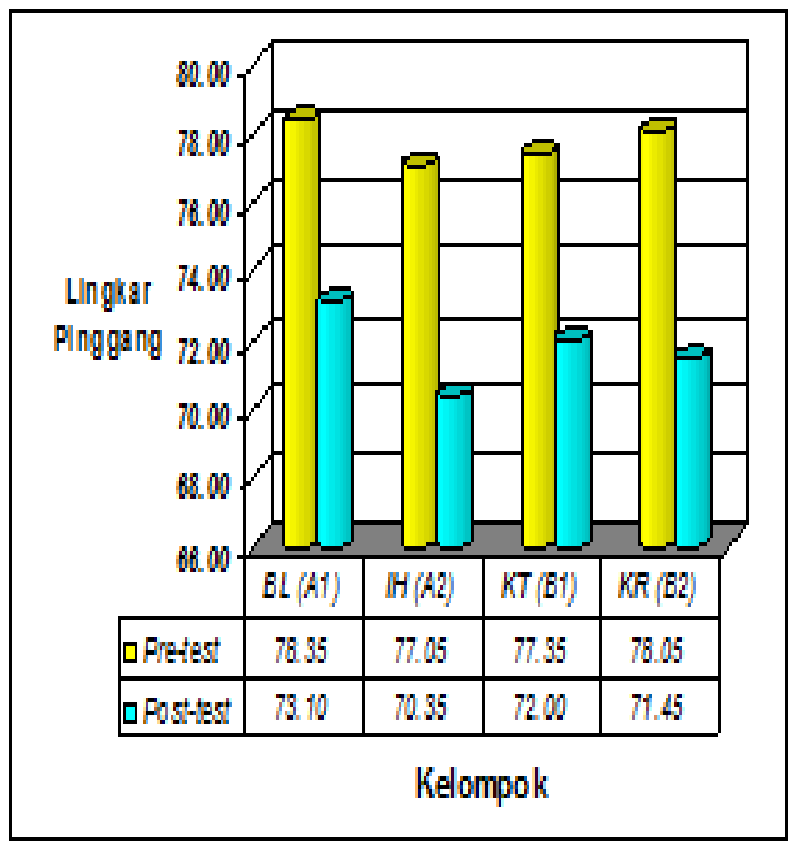

\title{
Figure 2. Histogram Average Value of Initial Test Results and Final Tests of Fat at Waist Each Group by Type of Gymnastic Exercise and Level of Flexibility
}

\author{
$\mathrm{BL}=$ Body language exercise training group \\ $\mathrm{IH}=$ Rhythm exercise group using hula-hoop \\ $\mathrm{KT}=$ High flexibility group \\ $\mathrm{KR}=$ Low flexibility group \\ $=$ Initial test results \\ $=$ Final test results
}


Table 3. Treatment Groups

\begin{tabular}{|r|c|c|}
\hline No & Treatment Groups (Se) & $\begin{array}{c}\text { Value of Decreasing Fat Levels at the } \\
\text { Waist }\end{array}$ \\
\hline 1 & $\mathrm{~A}_{1} \mathrm{~B}_{1}\left(\mathrm{KP}_{1}\right)$ & 3.80 \\
\hline 2 & $\mathrm{~A}_{1} \mathrm{~B}_{2}\left(\mathrm{KP}_{2}\right)$ & 6.70 \\
\hline 3 & $\mathrm{~A}_{2} \mathrm{~B}_{1}\left(\mathrm{KP}_{3}\right)$ & 6.90 \\
\hline 4 & $\mathrm{~A}_{2} \mathrm{~B}_{2}\left(\mathrm{KP}_{4}\right)$ & 6.50 \\
\hline
\end{tabular}

Information:

$\mathrm{KP} 1=$ Body language exercise group with high flexibility

KP 2 = Body language exercise group with low flexibility

KP 3 = Rhythm exercise group using hula-hoop with high flexibility

KP 4 = Rhythm exercise group using hula-hoop with low flexibility

\section{CONCLUSION}

Gymnastic methods, flexibility and obesity can influence the relationship between body mass index (BMI) and body fat percentage. Information about obesity is needed to find out how much someone wants to reduce the level of obesity and body fat, especially waist fat, which is the focus of this study. Gymnastics methods will affect physiological conditions physiologically; with exercise one can reduce body fat. In accordance with the focus of the research that will be studied by researchers is the reduction in waist fat in productive age women 35-45 years who have the will to exercise. Pilates gymnastics and rhythmic exercises using hula-hoop are effective in increasing the level of flexibility, cardiorespiratory endurance including resting pulse, blood pressure and breathing frequency. Both types of exercise (Pilates gymnastics and rhythmic exercises using hula hoops) can reduce body fat. Equality in Pilates gymnastics methods and rhythmic gymnastics methods using hula-hoop is the same form of body gymnastic exercise carried out by combining flexibility and endurance and body strength exercises, which are focused on strengthening the core of the abdomen and waist.

\section{ACKNOWLEDGMENT}

Sulfikar Sallu ID Scopus 57200989289 Lecturer at the Faculty of Information Technology, University Sembilanbelas November, Kolaka, Southeast Sulawesi, Indonesia.

\section{REFERENCES}

1. Lee Y, Kim M, Koo J. The impact of social interaction and team member exchange on sport event volunteer management. Sport Management Review. 2016;19(5):550-62.

2. Ao D, Wu F, Yun CF, Zheng XY. Trends in Physical Fitness Among 12-Year-Old Children in Urban and Rural Areas During the Social Transformation Period in China. J Adolesc Health. 2019;64(2):250-7.

3. Tian L, Wen AY, Dong SS, Xiao KY, Li H, Yan PS Excessive backfat of sows at mating promotes oxidative stress and up-regulates mitochondrial-mediated apoptotic pathway in the full-term placenta. Livestock Science. 2019;222:71-82.
4. Chiba R, Tominaga S, Mikami K, Kitajima M, Urushizaka M, Tomisawa T, et al. Factors Influencing Quality of Life in Stroke Patients: Focus on Eating Habits. J Stroke Cerebrovasc Dis. 2019.

5. Coccia M. The theory of technological parasitism for the measurement of the evolution of technology and technological forecasting. Technological Forecasting and Social Change. 2019;141:289-304.

6. Sinke WC. Development of photovoltaic technologies for global impact. Renewable Energy. 2019;138:911-4.

7. Liu L, Miura K, Kadota A, Fujiyoshi A, Gracely EJ, Xue $\mathrm{F}$, et al. The impact of sex on risk of cardiovascular disease and all-cause mortality in adults with or without diabetes mellitus: A comparison between the U.S. and Japan. J Diabetes Complications. 2019;33(6):417-23.

8. Brooker PG, Gomersall SR, King NA, Leveritt MD. The feasibility and acceptability of morning versus evening exercise for overweight and obese adults: A randomized controlled trial. Contemp Clin Trials Commun. 2019;14:100320.

9. Menchetti L, Vecchione L, Filipescu I, Petrescu VF, Fioretti B, Beccari T, et al. Effects of Goji berries supplementation on the productive performance of rabbit. Livestock Science. 2019;220:123-8.

10. Gepner Y, Shelef I, Komy O, Cohen N, Schwarzfuchs D, Bril N, et al. The Beneficial effects of Mediterranean diet over low-fat diet may be mediated by decreasing hepatic fat content. J Hepatol. 2019.

11. Mokkala K, Houttu N, Cansev T, Laitinen K. Interactions of dietary fat with the gut microbiota: Evaluation of mechanisms and metabolic consequences. Clinical Nutrition. 2019.

12. Maixner F, Turaev D, Cazenave-Gassiot A, Janko M, Krause-Kyora B, Hoopmann MR, et al. The Iceman's Last Meal Consisted of Fat, Wild Meat, and Cereals. Curr Biol. 2018;28(14):2348-55 e9.

13. Kim NK, Kang Y-S, Rie DH. Estimating toxic harmfulness based on quantitative analysis (I) - Factor analysis of harmfulness of combustion products on building materials. Fire Safety Journal. 2019;106:80-7.

14. Jiang GZ, Zhou M, Zhang DD, Li XF, Liu WB. The mechanism of action of a fat regulator: Glycyrrhetinic acid (GA) stimulating fatty acid transmembrane and intracellular transport in blunt snout bream (Megalobrama amblycephala). Comp Biochem Physiol A Mol Integr Physiol. 2018;226:83-90.

15. Santos S, Severo M, Gaillard R, Santos AC, Barros H, Oliveira A. The role of prenatal exposures on body fat patterns at 7 years: Intrauterine programming or birthweight effects? Nutr Metab Cardiovasc Dis. 2016;26(11):1004-10.

16. Barber TM, Franks S. Genetic and Environmental Factors in the Etiology of Polycystic Ovary Syndrome. 2019:437-59.

17. Cheng L, Chen X, Yang S, Cao Z, De Vos J, Witlox F. Active travel for active ageing in China: The role of built environment. Journal of Transport Geography. 2019;76:142-52.

18. Marcus JB. Diet and Disease: Healthy Choices for Disease Prevention and Diet Management. 2013:371430.

19. Pinto Pereira SM, Li L, Power C. Lifetime risk factors for leisure-time physical inactivity in mid-adulthood. Prev Med Rep. 2018;11:23-30. 


\section{AUTHORS PROFILE}

Eva Faridah is a lecturer from Faculty of Sport Sciences, Universitas Negeri Medan, Indonesia. She got undergraduate degree of Physical Education, Health and Recreation from Universitas Negeri Semarang, postgraduate degree of Sport Sciences from Universitas Sebelas Maret, Surakarta, and doctoral postgraduate degree of Sports Education from Universitas Negeri Semarang. E-mail: juna.fare178@gmail.com

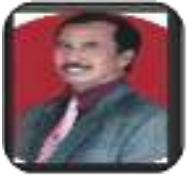

Soegiyanto KS is a Professor, teaching Sports Physiology at postgraduate Faculty of Sport Sciences, Universitas Negeri Semarang, Indonesia. $\mathrm{He}$ got undergraduate degree from Universitas Negeri Semarang, postgraduate degree from Univesitas Airlangga, and doctoral postgraduate from Universitas Negeri Semarang. E-mail: soegiyanto.ks@mail.unnes.ac.id

Nasuka is a lecturer from Faculty of Sport Sciences, Universitas Negeri Semarang, Indonesia. He got undergraduate degree of Sport Achievement from IKIP Semarang, postgraduate degree of Health Sports from Universitas Airlangga, Surabaya, and doctoral postgraduate degree of Physical Education from Universitas Negeri Semarang. E-mail: nasuka@mail.unnes.ac.id

Sulaiman is a lecturer from postgraduate Sport

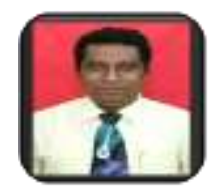
Education Universitas Negeri Semarang, Indonesia. He got undergraduate degree of Coaching Education Faculty of Sport Education and Health from IKIP Semarang, postgraduate degree of Sport Education from IKIP Jakarta, and doctoral postgraduate degree of Sport Education from Universitas Negeri Semarang. E-mail: sulaiman@mail.unnes.ac.id. 